\title{
Erratum to: Dehydroepiandrosterone (DHEA) supplementation results in supraphysiologic DHEA-S serum levels and progesterone assay interference that may impact clinical management in IVF
}

\author{
Jason M. Franasiak ${ }^{1,2} \cdot$ Semara Thomas $^{3} \cdot$ Susan $\mathrm{Ng}^{1} \cdot$ Maria Fano $^{1}$ • \\ Andrew Ruiz ${ }^{1}$ - Richard T. Scott Jr ${ }^{1,2}$ - Eric J. Forman ${ }^{1,2}$
}

Published online: 29 April 2017

(C) Springer Science+Business Media New York 2017

Erratum to: J Assist Reprod Genet (2016) 33:387-391

DOI 10.1007/s10815-016-0650-3

The units for DHEA-S in $\mu \mathrm{g} / \mathrm{mL}$ used in the manuscript were in error. The units throughout the manuscript for DHEA-S should have been $\mu \mathrm{g} / \mathrm{dL}$, as was used in Fig. 2 of the manuscript. DHEA-S controls from the manufacturer were supplied in $\mu \mathrm{g} / \mathrm{dL}$ units and yielded assay results in the reportable range of $\mu \mathrm{g} / \mathrm{dL}$.

The online version of the original article can be found at doi: http://dx.doi. org/10.1007/s10815-016-0650-3

Jason M. Franasiak

jfranasiak@rmanj.com

1 Reproductive Medicine Associates of New Jersey, Basking Ridge, NJ, USA

2 Rutgers, Robert Wood Johnson Medical School, New Brunswick, NJ, USA

3 Department of Obstetrics and Gynecology, University of Virginia, Charlottesville, VA, USA 